\title{
Microglia and Memory: Modulation by Early-Life Infection
}

\author{
Lauren L. Williamson, Paige W. Sholar, Rishi S. Mistry, Susan H. Smith, and Staci D. Bilbo \\ Department of Psychology and Neuroscience, Duke University, Durham, North Carolina 27708
}

\begin{abstract}
The proinflammatory cytokine interleukin- $1 \beta$ (IL-1 $\beta$ ) is critical for normal hippocampus (HP)-dependent cognition, whereas high levels can disrupt memory and are implicated in neurodegeneration. However, the cellular source of IL-1 $\beta$ during learning has not been shown, and little is known about the risk factors leading to cytokine dysregulation within the HP. We have reported that neonatal bacterial infection in rats leads to marked HP-dependent memory deficits in adulthood. However, deficits are only observed if unmasked by a subsequent immune challenge [lipopolysaccharide (LPS)] around the time of learning. These data implicate a long-term change within the immune system that, upon activation with the "second hit," LPS, acutely impacts the neural processes underlying memory. Indeed, inhibiting brain IL-1 $\beta$ before the LPS challenge prevents memory impairment in neonatally infected (NI) rats. We aimed to determine the cellular source of IL-1 $\beta$ during normal learning and thereby lend insight into the mechanism by which this cytokine is enduringly altered by early-life infection. We show for the first time that $\mathrm{CD} 11 \mathrm{~b}^{+}$enriched cells are the source of IL-1 $\beta$ during normal HP-dependent learning. $\mathrm{CD} 11 \mathrm{~b}^{+}$cells from NI rats are functionally sensitized within the adult $\mathrm{HP}$ and produce exaggerated IL-1 $\beta$ ex vivo compared with controls. However, an exaggerated IL-1 $\beta$ response in vivo requires LPS before learning. Moreover, preventing microglial activation during learning prevents memory impairment in NI rats, even following an LPS challenge. Thus, early-life events can significantly modulate normal learning-dependent cytokine activity within the HP, via a specific, enduring impact on brain microglial function.
\end{abstract}

\section{Introduction}

Immune molecules are increasingly implicated for their role in synaptic plasticity mechanisms within the brain, including memory. The proinflammatory cytokine interleukin- $1 \beta$ (IL-1 $\beta$ ) is induced within the hippocampus (HP) in response to normal learning and is critical for maintaining long-term potentiation (LTP) (Schneider et al., 1998; Ross et al., 2003). Moreover, mice lacking IL- $1 \beta$ or its type 1 receptor exhibit markedly impaired HP-dependent learning and memory (Goshen et al., 2007; Spulber et al., 2009). In contrast, high levels of IL- $1 \beta$ can profoundly impair memory (Barrientos et al., 2002, 2009) and are associated with Alzheimer's disease (AD) and other neurodegenerative disorders (Gallo et al., 1989; Griffin et al., 1989; Stanley et al., 1994; Meyers, 2000). These data suggest that physiological levels of IL- $1 \beta$ are necessary for normal memory, whereas concentrations that are either too low or too high impair memory (Ross et al., 2003; Goshen et al., 2007).

The mechanisms leading to cytokine dysregulation within the brain and thus risk factors for cognitive disorders remain poorly defined. However, research on "developmental programming" has begun to provide valuable insight into the origins of neuropsychiatric disorders that exhibit a broad spectrum of prevalence and severity (Bennet and Gunn, 2006). For instance, neonatal

\footnotetext{
Received July 19, 2011; revised Aug. 17, 2011; accepted Sept. 9, 2011.

Author contributions: S.D.B. designed research; L.L.W., P.W.S., R.S.M., S.H.S., and S.D.B. performed research; L.L.W., P.W.S., S.H.S., and S.D.B. analyzed data; L.L.W. and S.D.B. wrote the paper.

This work was supported by NIH Grant R01 (ARRA) MH083698 (S.D.B.). We thank Verne Tsang for technical assistance.

The authors declare no competing financial interests.

Correspondence should be addressed to Staci D. Bilbo, Department of Psychology and Neuroscience, Duke University, Durham, NC 27708. E-mail: staci.bilbo@duke.edu.

DOI:10.1523/JNEUROSCI.3688-11.2011

Copyright $\odot 2011$ the authors $\quad 0270-6474 / 11 / 3115511-11 \$ 15.00 / 0$
}

bacterial infection in rats leads to marked HP-dependent memory deficits in adulthood. However, deficits are only observed if unmasked by a subsequent immune challenge (peripheral LPS) $24 \mathrm{~h}$ before learning or immediately after learning. These data suggest the infection induces a long-term change within the immune system that, upon activation with the "second hit," LPS, acutely impacts the neural processes underlying memory (Bilbo et al., 2005a,b, 2006, 2008b; Bilbo and Schwarz, 2009). Indeed, preventing the synthesis of brain IL-1 $\beta$ before the LPS challenge completely prevents the memory impairment in neonatally infected (NI) rats (Bilbo et al., 2005b).

We aimed to determine the cellular source of IL- $1 \beta$ during normal learning and thereby lend insight into the mechanism by which this cytokine is enduringly altered by early-life infection. Microglia are the primary immune cells of the brain, are longlived, and have been linked to neurodegenerative disorders like AD (Streit, 2005, 2010). However, whether microglia and their inflammatory products are a cause or consequence of neural dysfunction remains subject to intense debate (Streit, 2010). We demonstrate that $\mathrm{CD}_{11 \mathrm{~b}}{ }^{+}$enriched cells (microglia/macrophages) are functionally primed within the adult HP of NI rats basally, and produce exaggerated IL- $1 \beta$ ex vivo. However, an exaggerated IL- $1 \beta$ response within the HP microglia of NI rats in vivo requires LPS before learning. Furthermore, preventing microglial activation during learning prevents memory impairment in NI rats, even if preceded by LPS. Together, these data directly implicate microglial-derived IL- $1 \beta$ in normal learning for the first time. Importantly, they suggest an individual's risk or resilience to neuroinflammatory disorders may critically depend on their early life experience, which can modulate normal cognitiondependent cytokine activity within the brain long after the initial insult. 


\section{Materials and Methods}

\section{Animals}

Adult male and female Sprague Dawley rats $(70 \mathrm{~d})$ were obtained from Harlan and housed in same-sex pairs in individually ventilated, microisolator polypropylene cages, with ad libitum access to food and filtered water. The colony was maintained at $22^{\circ} \mathrm{C}$ on a $12 \mathrm{~h}$ light/dark cycle (lights on at 7:00 A.M.). Following acclimation to laboratory conditions, males and females were paired into breeders. Sentinel animals were housed in the colony room and screened periodically for the presence of common rodent diseases; all screens were negative. All experiments were conducted with protocols approved by the Duke University Animal Care and Use Committee.

\section{Neonatal manipulations \\ Bacterial culture}

Escherichia coli culture (ATCC 15746; American Type Culture Collection) vial contents were hydrated and grown overnight in $30 \mathrm{ml}$ of brainheart infusion (BHI) (Difco) at $37^{\circ} \mathrm{C}$. Cultures were aliquoted into $1 \mathrm{ml}$ stock vials supplemented with $10 \%$ glycerol and frozen at $-20^{\circ} \mathrm{C}$. One day before injections, a stock culture was thawed and incubated overnight in $40 \mathrm{ml}$ of $\mathrm{BHI}$ at $37^{\circ} \mathrm{C}$. The number of bacteria in cultures was read using a microplate reader (Bio-Tek Instruments) and quantified by extrapolating from previously determined growth curves. Cultures were centrifuged for $15 \mathrm{~min}$ at $4000 \mathrm{rpm}$, the supernatants were discarded, and the bacteria were resuspended in the dose-appropriate volume of sterile Dulbecco's PBS (Invitrogen).

\section{Injections}

Female breeders were visually examined daily for confirmation of pregnancy, and male breeders were removed from cages before the birth of pups [postnatal day $0(\mathrm{P} 0)$ ]. Litters were culled on $\mathrm{P} 4$ to a maximum of 10 pups/litter, retaining 2 females and as many male pups as possible. Male pups were injected subcutaneously ( 30 ga needle) on P4 with either $0.1 \times$ $10^{6}$ colony forming units of live bacterial $E$. coli/gram suspended in 0.1 $\mathrm{ml}$ of PBS ("NI rats"), or $0.1 \mathrm{ml}$ of PBS ("control rats"). This dose of $E$. coli results in sustained $(\sim 48-72 \mathrm{~h})$ increased plasma cytokines (IL-1 $\beta$, IL-6) and corticosterone, as well as specific increases in IL- $1 \beta$ mRNA and related genes (IL-1 type 1 receptor, caspase 1) within the brain by $24 \mathrm{~h}$ after infection (Bilbo et al., 2005b; Schwarz and Bilbo, 2011). All pups were removed from the mother at the same time and placed into a clean cage with bedding, weighed and injected individually, and returned to the mother as a group. Elapsed time away from the mother was $<5 \mathrm{~min}$. All pups from a single litter received the same treatment due to concerns over possible cross-contamination from E. coli. All injections were given between 2:00 P.M. and 4:00 P.M. All male pups for adult analyses were weaned on P21 and housed in sibling pairs; remaining female pups were killed. To control for litter effects, a maximum of two pups per litter across a minimum of three different litters were assigned to a single experimental group. All rats were tested as adults between 65 and $90 \mathrm{~d}$ of age.

\section{Behavioral procedures}

\section{Contextual and auditory cue fear conditioning}

Apparatus. The conditioning context consisted of one of two identical black Plexiglas boxes with open fronts [41.9 cm length (L) $\times 40.6 \mathrm{~cm}$ width $(\mathrm{W}) \times 46.2 \mathrm{~cm}$ height $(\mathrm{H})]$ to allow viewing of animals. The conditioning chambers $[30.5 \mathrm{~cm}(\mathrm{~L}) \times 26.7 \mathrm{~cm}(\mathrm{~W}) \times 33 \mathrm{~cm}(\mathrm{H})]$, placed inside each black box, are made of clear Plexiglas with metal side walls (Coulbourn Instruments). Each chamber has a ceiling-mounted infrared activity monitor connected to a PC. A phasic auditory cue ( $2976 \mathrm{~Hz}$ tone presented at $76 \mathrm{~dB}$ ) is also mounted on the ceiling of each black box. A $2 \mathrm{~s}, 1.5 \mathrm{~mA}$ shock is delivered through a removable floor of stainless-steel rods. Each rod is $0.5 \mathrm{~cm}$ in diameter, is spaced $1.75 \mathrm{~cm}$ center to center, and is wired to a shock generator and scrambler. The chamber was cleaned with $70 \%$ alcohol and then water before each animal.

Procedure. Rats were allowed to explore the chamber for $2 \mathrm{~min}$ before the onset of a $15 \mathrm{~s}$ tone, followed immediately by a $2 \mathrm{~s}$ footshock $(1.5 \mathrm{~mA})$.
Immediately after the termination of the shock, rats were removed from the chamber. Rats were tested 1 or $72 \mathrm{~h}$ later for contextual fear in the original conditioning chamber for $6 \mathrm{~min}$. For assessment of auditory-cue fear ( $3 \mathrm{~h}$ after $72 \mathrm{~h}$ context test), testing occurred in a novel chamber with triangular Plexiglas walls. The rod floors were removed, and a $7 \mathrm{~W}, 120 \mathrm{~V}$ AC clear, red light bulb illuminated the chests. Freezing was again assessed for $6 \mathrm{~min}$. The auditory conditioned stimulus (CS) was absent for the first $3 \mathrm{~min}$ (pre-CS) and present for the last $3 \mathrm{~min}$ (CS period). Freezing represents rats' dominant defensive fear response and is characterized by an immediate suppression of behavior accompanied by immobility, shallow breathing, and a variety of other autonomic changes, including an increase in heart rate and piloerection. Freezing in these experiments was defined as the absence of all visible movement, except for respiration. Scoring began $10 \mathrm{~s}$ after the animal was placed into the chamber.

\section{Open field}

To assess overall activity levels in unmanipulated rats treated with water versus minocycline (MINO) (50 mg/kg $12 \mathrm{~h}$ prior plus $25 \mathrm{mg} / \mathrm{kg} 1 \mathrm{~h}$ prior via oral gavage), rats were placed into a novel open field $[45.1 \mathrm{~cm}(\mathrm{~W}) \times$ $40.0 \mathrm{~cm}(\mathrm{~L}) \times 34.9 \mathrm{~cm}(\mathrm{H})]$ beginning $1 \mathrm{~h}$ after the final dose, and scored for $10 \mathrm{~min}$ using automated tracking software (ANYmaze; Stoelting).

\section{Drugs}

LPS derived from E. coli (serotype 0111:B4; Sigma-Aldrich) was suspended in sterile saline and administered via intraperitoneal injection at a dose of $25 \mu \mathrm{g} / \mathrm{kg}$ and a volume of $1 \mathrm{ml} / \mathrm{kg}$. This dose was selected based on our previous body of work (Bilbo et al., 2005a,b, 2006, 2007, 2008a,b, 2010; Bilbo and Schwarz, 2009; Bland et al., 2010). Minocycline hydrochloride (Sigma-Aldrich) was dissolved in water to a dose of 50 or 25 $\mathrm{mg} / \mathrm{kg}$ in a volume of $5 \mathrm{ml} / \mathrm{kg}$ and administered via oral gavage ( $=10$ and $5 \mathrm{mg} / \mathrm{ml}$, respectively) using animal feeding needles (Harvard Apparatus; catalog \#52-4199). The average body weight of the adult rats was $400 \mathrm{~g}$. Rats were acclimated to the procedure using water for $3 \mathrm{~d}$ before each experiment.

\section{Tissue collection}

Adult rats were deeply anesthetized with a ketamine/xylazine mixture and transcardially perfused with ice-cold saline for 2 min to clear brain vessels of blood and peripheral cells. Brains were extracted and immediately dissected into prefrontal cortex (PFC), HP, and adjacent parietal cortex (PCX), depending on experiment, on an ice-chilled plate. Each region was cut in one-half along the sagittal plane, and one-half regions to be used for mRNA and protein analysis were placed into separate RNase- and endotoxin-free microcentrifuge tubes and snap frozen in liquid nitrogen. Tissues were stored at $-80^{\circ} \mathrm{C}$ until processing. Brain hemispheres collected for assessment of protein versus mRNA were alternated between animals and distributed equally across groups.

\section{IL-1 $\beta$ ELISA}

Brain tissue samples were sonicated in cold Iscove's culture medium containing $5 \%$ fetal calf serum and a mixture enzyme inhibitor (in mM: 100 amino- $n$-caproic acid, 10 EDTA, 5 benzamidine- $\mathrm{HCl}$, and 0.2 phenylmethylsulfonyl fluoride), and IL- $1 \beta$ was measured from the supernatant using a commercially available ELISA kit (R\&D Systems). The detection limit for IL- $1 \beta$ was $5 \mathrm{pg} / \mathrm{ml}$. To adjust for variability in tissue sample sizes, total protein concentrations were determined by Coomassie Brilliant Blue AG-250 protein assay (180). Cytokine data are expressed as picograms per $100 \mu \mathrm{g}$ of total protein.

\section{Real-time qPCR}

For whole tissues, total RNA was isolated based on the TRIzol method (Chomczynski and Sacchi, 1987). Following RNA isolation and enrichment, samples were DNase-treated, and cDNA was synthesized using the reverse transcriptase kit from QIAGEN. Amplification of cDNA was performed using a QuantiFast SYBR Green PCR kit (QIAGEN) on a Mastercycler ep realplex (Eppendorf). cDNA $(1.5 \mu \mathrm{g}$ in $1 \mu \mathrm{l})$ was added to a reaction master mix $(12 \mu \mathrm{l})$ containing HotStarTaq Plus DNA Polymer- 
Table 1. Primer sequences

\begin{tabular}{lll}
\hline Gene & Forward $5^{\prime}-3^{\prime}$ & Reverse $5^{\prime}-3^{\prime}$ \\
\hline CD11b & ctgggagatgtgaatggag & actgatgctggctactgatg \\
GFAP & agggacaatctcacacagg & gactcaaccttcctctcca \\
IL-1 & gaagtcaagaccaaagtgg & tgaagtcaactatgtcccg \\
CX3CL1 & tccagggctgtccccgcaaa & acaggcaggcaagcaggcag \\
CX3CR1 & ttcctcttctggacgcctta & taaacgccactgtctccg \\
GAPDH & gtttgtgatgggtgtgaacc & tcttctgagtggcagtgatg \\
18S & atggtagtcgccgtgccta & ctgctgccttccttggatg \\
\hline
\end{tabular}

ase, QuantiFast Buffer, SYBR Green I, Passive reference dye, and genespecific primers (500 nM each of forward and reverse primer). Threshold cycle $\left(\mathrm{C}_{\mathrm{T}}\right)$ (number of cycles to reach threshold of detection) was determined for each reaction, and relative gene expression was determined using the $2^{-\Delta \Delta \mathrm{Ct}}$ method (Livak and Schmittgen, 2001; Pfaffl, 2001) as follows: (1) we normalized the cycle threshold $\left(\mathrm{C}_{\mathrm{T}}\right)$ of the target gene of interest $(\mathrm{T})$ to that of the reference (housekeeping) gene $(\mathrm{R})$, for both the test (A) and calibrator samples (B): $\Delta \mathrm{C}_{\mathrm{T}(\mathrm{A})}=\mathrm{C}_{\mathrm{T}(\mathrm{T}, \mathrm{A})}-\mathrm{C}_{\mathrm{T}(\mathrm{R}, \mathrm{A})}$ and $\Delta \mathrm{C}_{\mathrm{T}(\mathrm{B})}=\mathrm{C}_{\mathrm{T}(\mathrm{T}, \mathrm{B})}-\mathrm{C}_{\mathrm{T}(\mathrm{R}, \mathrm{B})}$. We define the calibrator sample as that with the lowest (baseline) expression. (2) We normalized the $\Delta \mathrm{C}_{\mathrm{T}}$ of A to B: $\Delta \Delta \mathrm{C}_{\mathrm{T}}=\Delta \mathrm{C}_{\mathrm{T}(\mathrm{A})}-\Delta \mathrm{C}_{\mathrm{T}(\mathrm{B})}$, and (3) we calculated the expression ratio: $2^{-\Delta \Delta \mathrm{CT}}=$ normalized expression ratio.

\section{Primer specifications}

Primer pairs for CD200 and CD200R were purchased from QIAGEN. We designed primers for CD11b, glial fibrillary acidic protein (GFAP), IL$1 \beta$, CX3CL1, CX3CR1, GAPDH, and 18s: cDNA sequences were obtained from GenBank at the National Center for Biotechnology Information (NCBI) (www.ncbi.nlm.nih.gov) and designed using an online Oligo Analysis and Plotting Tool (QIAGEN), which were tested for sequence specificity using the basic local alignment search tool at NCBI. Primers were obtained from Sigma-Aldrich, and specificity was verified by melt curve analysis. We estimated the efficiency of each primer set based on serial dilution standard curves. All primer sets were estimated as $>90 \%$ efficient, and within $5 \%$ of each other. Primer sequences are displayed in Table 1.

\section{Microglial isolation}

Isolated HPs were sliced into small pieces using a sterile razor and transferred into a $2 \mathrm{ml}$ sterile tube with $1 \mathrm{ml}$ of HBSS (w/o) (Invitrogen), which was spun at $300 \times g$ at room temperature for $2 \mathrm{~min}$. HP tissue was then brought to a single-cell suspension using Miltenyi's Neural Tissue Dissociation Kit (P) (Miltenyi Biotec), according to the manufacturer's instructions. After a final wash in $\mathrm{HBSS}$ containing $\mathrm{CaCl}_{2}$ and $\mathrm{MgCl}_{2}, \mathrm{HP}$ tissue was incubated with anti-myelin microbeads (Miltenyi Biotec) in MACS buffer (PBS containing 0.5\% BSA and 2 mм EDTA, pH 7.2) for 15 min at $4^{\circ} \mathrm{C}$. HP tissue was then washed with $5 \mathrm{ml}$ of MACS buffer and centrifuged at $300 \times g$ at $4^{\circ} \mathrm{C}$ for $10 \mathrm{~min}$. The tissue was resuspended in $500 \mu \mathrm{l}$ of MACS buffer and passed through a nylon filter onto LD columns (Miltenyi Biotec) exposed to a strong magnetic field. The flow through (demyelinated HP cells) and subsequent washes were collected into a new $15 \mathrm{ml}$ conical and centrifuged at $300 \times g$ at $4^{\circ} \mathrm{C}$ for $10 \mathrm{~min}$. The demyelinated HP cells were immediately taken for flow-cytometric analysis (see Fig. 5) or further fractionated based on CD11b expression as follows.

\section{MACS enrichment of $C D 11 b^{+}$cells}

Cells were resuspended in $500 \mu \mathrm{l}$ of MACS buffer, stained with $5 \mu \mathrm{l}$ of $\mathrm{PE}$-conjugated mouse anti-rat CD11b/c (BD Biosciences Pharmingen) and incubated for $10 \mathrm{~min}$ in the dark at $4^{\circ} \mathrm{C}$. The cells were washed with $5 \mathrm{ml}$ of MACS buffer and centrifuged at $300 \times g$ at $4^{\circ} \mathrm{C}$ for $10 \mathrm{~min}$. Cells were then incubated with anti-PE MicroBeads (Miltenyi Biotec) at $4^{\circ} \mathrm{C}$ for $15 \mathrm{~min}$. The suspension was washed with $5 \mathrm{ml}$ of MACS buffer and centrifuged at $300 \times g$ at $4^{\circ} \mathrm{C}$ for $10 \mathrm{~min}$, and the supernatant was aspirated off. The cells were resuspended in $500 \mu$ l of MACS buffer and were passed through a nylon mesh filter onto magnetized LS columns (Miltenyi Biotec). The columns were washed with $4 \mathrm{ml}$ of MACS buffer and the flow through either collected into a clean $15 \mathrm{ml}$ conical (as CD11b/cnegative fraction) or discarded. Magnetically labeled CD11b/c-positive cells were flushed out of the columns twice with MACS buffer into a clean $15 \mathrm{ml}$ conical. Magnetically enriched cell fractions were centrifuged at $300 \times g$ at $4^{\circ} \mathrm{C}$ for $10 \mathrm{~min}$, followed by resuspension in $500 \mu \mathrm{l}$ of PBS (Invitrogen) or Neuro Media (high-glucose DMEM supplemented with $20 \% \mathrm{FBS}$ and $5 \mu \mathrm{g} / \mathrm{ml}$ forskolin). Isolated $\mathrm{CD}_{11 \mathrm{~b}^{+}}$and $\mathrm{CD} 1 \mathrm{~b}^{-}$cells were then taken for flow-cytometric analysis (see Fig. $6 a$ ), immediately lysed for RT-PCR analysis (see Fig. 7), or placed into culture as follows.

Ex vivo LPS stimulation

Isolated $\mathrm{CD}_{11 \mathrm{~b}^{+}}$or $\mathrm{CD} 11 \mathrm{~b}^{-}$cells were suspended in high-glucose DMEM plus $20 \%$ FBS and $5 \mu \mathrm{g} / \mathrm{ml}$ forskolin and plated in 96 -well round-bottom plates at a density of $2 \times 10^{5}$ cells $/ 200 \mu \mathrm{l} /$ well. Cells were incubated with LPS $(10 \mathrm{ng} / \mathrm{ml})$ or media alone for $4 \mathrm{~h}$ at $37^{\circ} \mathrm{C}, 5 \% \mathrm{CO}_{2}$. For each condition, samples were run in duplicate. At the end of incubation, the plate was centrifuged at $1000 \times g$ for $10 \mathrm{~min}$ at $4^{\circ} \mathrm{C}$ to pellet cells. For RNA isolation, medium was removed and cDNA synthesized using the SuperScript III CellsDirect cDNA synthesis system (Invitrogen), according to the manufacturer's instructions. Real-time qPCR was performed as described above, and the level of IL-1 $\beta$ mRNA was quantified relative to the housekeeping gene $18 \mathrm{~s}$.

\section{Fluorescence staining and flow cytometry}

Demyelinated or MACS-enriched HP cells were washed once in PBS supplemented with $0.5 \%$ BSA and 2 mм EDTA (MACS buffer), followed by centrifugation at $350 \times g$ for $5 \mathrm{~min}$. MACS buffer was removed by decanting or aspiration and the pellet dispersed with agitation. Cells were incubated with $5 \mu \mathrm{l}$ of rat Fc receptor block (CD32; BD Biosciences Pharmingen) for $5 \mathrm{~min}$ at $4^{\circ} \mathrm{C}$. Next, $100 \mu \mathrm{l}$ of PE-conjugated mouse anti-rat CD11b/c (BD Biosciences Pharmingen), diluted 1:500 in MACS buffer, was added, and cells were incubated for $15 \mathrm{~min}$ at $4^{\circ} \mathrm{C}$ in the dark. Because CD11b/c labels all macrophages, $\mathrm{CD} 11 \mathrm{~b}^{+}$cells in a control experiment were incubated in anti-CD11b/c-PE and anti-CD45-FITC (BD Biosciences Pharmingen) to determine the relative concentration of perivascular macrophages, which label as $\mathrm{CD} 11 \mathrm{~b}^{+} / \mathrm{CD} 45^{\text {high }}$ (Ford et al., 1995). Cells were washed in MACS buffer, spun down at $350 \times g$ for $5 \mathrm{~min}$, and then fixed in $200 \mu \mathrm{l}$ of $1.5 \%$ paraformaldehyde before analysis using a FACSCanto II flow cytometer (BD Biosciences) and FlowJo software (Tree Star). For each sample, 10,000 events were collected and doublets were excluded from the analysis based on properties of size (forward scatter height and area).

\section{Data analysis and statistics}

Data were analyzed using SigmaStat statistical software. For significant $F$ scores, Holm-Sidak post hoc comparisons were performed to further distinguish among groups, and all differences were considered statistically significant if $p<0.05$.

\section{Results}

Learning increases IL-1 $\boldsymbol{\beta}$ protein specifically within the hippocampus, and this increase is modulated by neonatal infection

We have reported that systemic infection with E. coli on P4 leads to marked HP-dependent memory impairment in adulthood, but only if these animals receive a low-dose LPS challenge after learning. The impairment is causally linked to exaggerated CNS IL- $1 \beta$ production, as preventing IL- $1 \beta$ synthesis within the brain completely prevents the memory impairment (Bilbo et al., 2005b). Peripheral cytokine levels do not differ between groups in response to LPS, suggesting the critical difference within the brain is not due to a differential signal from the periphery (Bilbo et al., 2005b). Curiously, LPS $24 \mathrm{~h}$ prior to learning also impairs long-term contextual memory in NI but not control rats despite the fact that HP IL- $1 \beta$ is largely undetectable in both groups $24 \mathrm{~h}$ after an LPS injection alone (Bilbo et al., 2005b, 2006). These data led us to test the hypothesis that learning itself induces IL- $1 \beta$ 
a

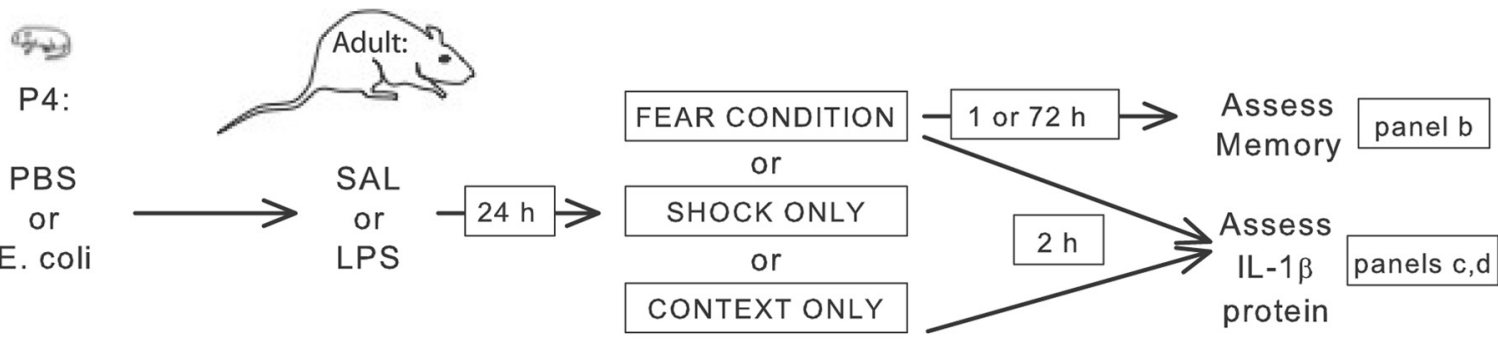

b

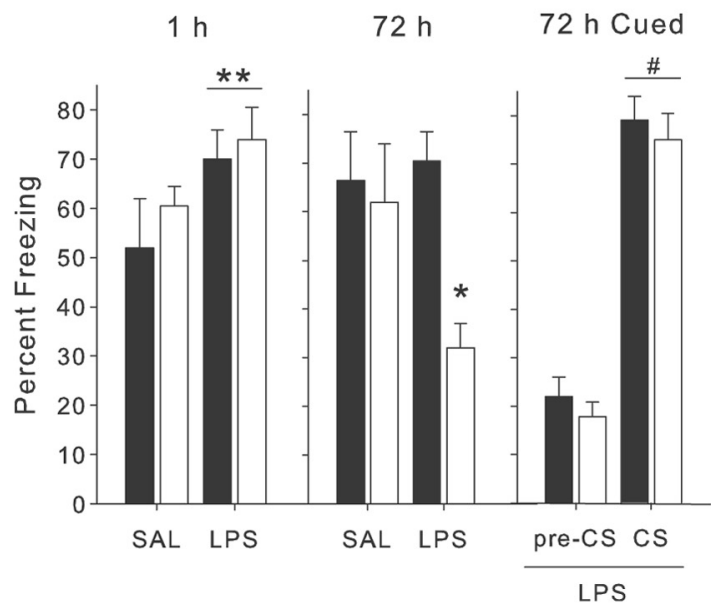

C

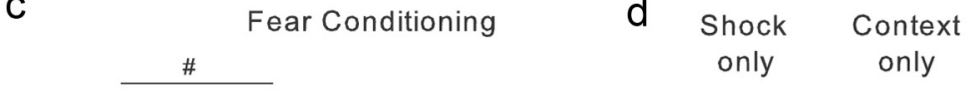

Figure 1. Learning increases IL-1 $\beta$ protein specifically within the hippocampus, and this increase is modulated by neonatal infection. $\boldsymbol{a}$, Rats treated with PBS or $E$. coli on P4 were injected as adults with saline (SAL) or LPS, and fear conditioned $24 \mathrm{~h}$ later ( $n=8 / \mathrm{group}$ ). Memory was assessed 1 or $72 \mathrm{~h}$ after conditioning. A separate group of rats from each neonatal treatment were injected as adults with SAL or LPS, and $24 \mathrm{~h}$ later received Fear Conditioning, Shock only, or Context exposure only ( $n=8 / \mathrm{grp})$. Brains were collected $2 \mathrm{~h}$ later to assess IL- $1 \beta$ protein. $\boldsymbol{b}$, Freezing to the context did not differ between groups at the $1 \mathrm{~h}$ test, although freezing was greater overall in LPS-injected rats $\left({ }^{* *} p<0.05\right)$. At the $72 \mathrm{~h}$ test, freezing to the context was significantly lowest in $\mathrm{NI}$ rats treated with LPS $24 \mathrm{~h}$ prior $\left({ }^{*} p<0.001\right)$. Freezing to the tone cue (CS) in an altered environment was significantly greater than the pre-CS period, but there was no neonatal group difference ( $\left.{ }^{\#} p<0.001\right)$. c, IL-1 $\beta$ was exaggerated within the HP of NI rats following LPS ( $\left.{ }^{*} p<0.02\right)$. Moreover, IL-1 $\beta$ was detectable only in HP following SAL injection $\left({ }^{* *} p<0.001\right)$, and concentrations were highest overall in HP ( $\left.{ }^{\#} p<0.001\right)$. d, Neither Shock nor Context alone produced the same exaggerated response within the HP of NI plus LPS rats, and concentrations were undetectable $24 \mathrm{~h}$ after SAL. Error bars indicate SEM.

protein within the HP, which is differentially modulated in NI rats. To test this, rats treated with PBS or E. coli on P4 were injected intraperitoneally with saline (SAL) or LPS as adults, and fear conditioned 24 h later ( $n=8$ /group) (Fig. 1a). Rats were assessed for memory $72 \mathrm{~h}$ after fear conditioning. Figure $1 b$ illustrates that freezing to the context did not differ by neonatal treatment group at the short-term $(1 \mathrm{~h})$ memory test. Interestingly, there was a main effect of injection $\left(F_{(1,31)}=4.5 ; p=0.04\right)$, as rats injected with LPS froze more overall than rats injected with saline. At the long-term test $(72 \mathrm{~h})$, there was a significant interaction between neonatal group and adult injection $\left(F_{(1,31)}=12.7\right.$; $p=0.001)$. Post hoc tests revealed that freezing was significantly lowest in the NI plus adult LPS group. In contrast to contextual memory, which depends on the HP, freezing to the tone did not differ by neonatal group in LPS-injected rats at the $72 \mathrm{~h}$ test, either before the tone presentation (pre-CS) or during the tone (CS). As expected, freezing was significantly greater to the CS than during the pre-CS period in all rats $\left(F_{(1,31)}=61.6 ; p<0.001\right)$.

In a second group of rats from each group, brains were collected $2 \mathrm{~h}$ after fear conditioning to assess whether learning induces IL- $1 \beta$ protein within the HP, and whether this is altered by neonatal infection ( $n=8 /$ group). Figure $1 c$ illustrates that IL- $1 \beta$ protein is markedly exaggerated within the HP of NI rats that received LPS $24 \mathrm{~h}$ before Fear Conditioning [main effects of neonatal treatment $\left(F_{(1,31)}=6.24 ; p<0.02\right)$ and adult injection
$\left.\left(F_{(1,31)}=6.21 ; p<0.02\right)\right]$, but not within either cortical region $(p>0.05)$. In a second experiment, adult rats from each neonatal group were injected with either SAL or LPS $24 \mathrm{~h}$ before an immediate $2 \mathrm{~s}$ Footshock only, or to a $5 \mathrm{~min}$ Context exposure only. Notably, LPS before either Shock alone or Context alone did not similarly exaggerate IL- $1 \beta$ within the HP ( $p>0.05$ for both) (Fig. $1 d)$. Importantly, a saline injection $24 \mathrm{~h}$ before either Shock or Context did not yield detectable IL- $1 \beta$ protein within the HP, indicating that learning is necessary to elicit the production of IL- $1 \beta$ within the HP [ANOVA on ranks for all saline-injected rats $(H=24.1, \mathrm{df}=2, p<0.001$; Conditioned $>$ Shock and Context)]. Finally, we assessed whether observed increases in IL- $1 \beta$ in the saline before conditioned group differed by brain region; there was a significant main effect of region $\left(F_{(1,47)}=29 ; p<\right.$ 0.001), with concentrations higher in HP than either PCX or PFC. Based on these data, we included only the HP of Fear Conditioned and Shock only groups for all further analyses.

\section{Microglial but not astroglial activation marker expression within the hippocampus reflects the pattern of IL-1 $\beta$}

Microglia and resident macrophages are a major source of IL- $1 \beta$ within the brain. However, many other cell types, including astrocytes and neurons, can produce IL- $1 \beta$ within the brain (Rothwell, 1991). To determine whether microglia/macrophages are the source of IL- $1 \beta$ during nonpathological conditions, specifically during learning, we assessed expression 


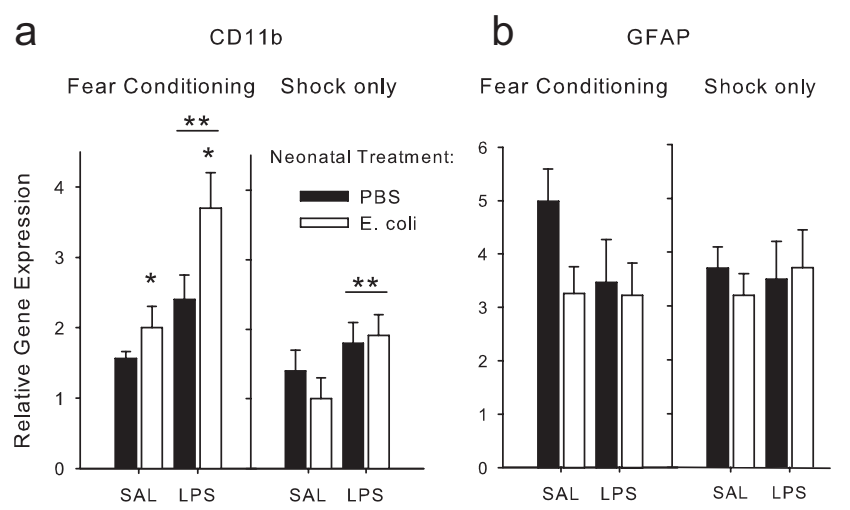

Figure 2. Microglial activation within the HP is exaggerated in NI rats, but only in response to learning. Rats treated with PBS or E. coli on P4 were injected as adults with SAL or LPS, and $24 \mathrm{~h}$ later received Fear Conditioning or Shock only ( $n=8 /$ group). Brains were collected $2 \mathrm{~h}$ later, and CD11b and GFAP were assessed. $a$, CD11b relative expression to GAPDH was increased by LPS $\left({ }^{* *} p<0.02\right.$ ) and exaggerated within the HP of NI rats (overall effect of $E$. coli, ${ }^{*} p<$ 0.02). Shock alone did not produce the same exaggerated response within the HP of NI rats, although there was a significant effect of LPS $\left({ }^{* *} p<0.05\right)$. $\boldsymbol{b}$, GFAP expression did not significantly differ among groups, either following Fear Conditioning or Shock alone $(p>0.05$ for both). Error bars indicate SEM.

levels of CD11b and GFAP, two activity-dependent surface antigens present on microglia/perivascular macrophages, and astrocytes, respectively, within the opposite hemisphere of hippocampi assessed for IL- $1 \beta$ in Figure 1. For CD11b, there were significant main effects of neonatal group $\left({ }^{\star} E\right.$. coli $>$ PBS) and injection ( ${ }^{* *}$ LPS $>$ SAL $)\left(F_{(1,31)}>6.1 ; p<0.02\right.$, for each) after Fear Conditioning (Fig. $2 a$ ). In contrast, there were no significant effects of neonatal treatment on CD11b expression in rats that received LPS $24 \mathrm{~h}$ before Shock only $(p>$ $0.05)$. However, there was a significant effect of LPS $\left(F_{(1,31)}>\right.$ $6.9 ; p<0.01)$. For GFAP, there were no significant group differences in either Fear Conditioned or Shock only groups $(p>0.05$, for both; Fig. $2 b)$.

\section{NI rats exhibit decreased neuronal inhibition within the hippocampus during learning compared with controls} Our preliminary data suggest that microglia are more reactive to LPS in NI rats. Microglial activity is modulated in part via direct contact with neurons and their surface-expressed and secreted products. For instance, CD200 interacts with CD200R on myeloid cells and CX3CL1 (fractalkine) can bind to its receptor (CX3CR1) on microglia (Harrison et al., 1998; Barclay et al., 2002). We determined expression levels for each of these factors in the same HP tissues presented above in Figure 2. In the Fear Conditioned group, there was a significant effect of neonatal treatment on $\operatorname{CD} 200\left(F_{(1,31)}=6.7 ; p=0.01\right)$, with expression lowest overall in NI rats, and significant effects of neonatal treatment $\left(F_{(1,31)}=15 ; p<0.001\right)$ and injection $\left(F_{(1,31)}=7.1 ; p<\right.$ 0.02 ) on CD200R (Fig. $3 a$ ). In the Shock only group, there was a significant effect of injection on both CD200 and its receptor $\left(F_{(1,31)}=7.1, p<0.02\right.$, for both; SAL $>$ LPS $)$, but no neonatal group difference (Fig. $3 b$ ). Thus, the decreased neuronal inhibition in NI rats compared with controls depends on learning. In contrast, there were no significant differences in CX3CL1 in either the Fear Conditioned (Fig. 3c) or Shock only (Fig. 3d) group; however, there was a significant effect of neonatal treatment on its receptor CX3CR1 $\left(F_{(1,31)}>5, p<0.04\right.$; PBS $>$ E. coli, for both).
Hippocampal microglia from NI rats express greater levels of CD11b on a per-cell basis compared with controls

We have demonstrated that microglia show a marked increase in CD11b mRNA within the HP in response to the peripheral infection on $\mathrm{P} 4$, and that this increase is both sustained into adulthood, and exaggerated in response to LPS in NI compared with control rats (Bilbo et al., 2005b, 2007). Moreover, the number of microglia does not differ within the adult $\mathrm{HP}$ as a consequence of neonatal infection (Bland et al., 2010). Rather, the morphology of the cells is altered-microglial cell volumes are larger, with shorter, thicker processes in adult rats infected as neonates compared with controls (Bland et al., 2010). These combined data suggest that changes in the function of microglia, rather than changes in number, may underlie the increased reactivity observed in adult NI rats, consistent with glial sensitization or priming.

To assess this directly, the HP was collected from adult rats in each neonatal condition. Before tissue harvest, rats were perfused with cold saline to eliminate infiltrating cells. Dissected hippocampi were brought to single-cell suspensions using Miltenyi's Neural Dissociation Kit (P) (Miltenyi Biotec) followed by myelin depletion and staining with APC-conjugated CD11b. Expression was quantified using a FACSCanto II flow cytometer (Beckman Coulter) and analyzed using FlowJo software (Tree Star) (Fig. $4 a)$. The mean fluorescence intensity (MFI) of CD11b expression on gated microglia $\left(\mathrm{CD}_{1} 1 \mathrm{~b}^{+}\right)$was significantly greater on a percell basis in NI $(n=10)$ compared with PBS $(n=9)$ rats $\left(t_{(17)}=\right.$ 2.5; $p=0.02$ ) (Fig. $4 b$ ). Notably, the relative frequency of $\mathrm{CD}_{11 \mathrm{~b}}{ }^{+}$cells in our mixed cell population did not differ between groups. These data are pooled from five independent isolations of two animals per treatment group per day. In a separate experiment, myelin-depleted cells from rats in each neonatal treatment group were sorted into $\mathrm{CD}_{1} 1 \mathrm{~b}^{+}$and $\mathrm{CD} 11 \mathrm{~b}^{-}$fractions using magnetic beads. A rightward shift can be seen in the population of $\mathrm{CD}_{1} \mathrm{bb}^{+}$cells from NI rats, indicating increased expression (vertical line is provided for comparison) (Fig. 4c). Notably, the increased surface expression of CD11b in E. coli rats in both preparations indicates the increase observed in Figure $4 b$ is not altered by the MACS enrichment step. Moreover, both increases were independent of any adult challenge, suggesting that surface antigen expression of microglia may be permanently altered as a consequence of the neonatal infection. Finally, a subset of sorted $\mathrm{CD}_{11 \mathrm{~b}}{ }^{+}$cells were stained with APC-conjugated CD11b/c and CD45 (a marker highly expressed on infiltrating macrophages), which revealed a large, dense cluster of CD $11 \mathrm{~b}^{\text {high }} / \mathrm{CD} 45^{\text {low }}$ cells. In contrast, $\mathrm{CD} 11 \mathrm{~b}^{\text {high }}$ cells that also stained brightly for CD45 accounted for only $4.2 \%$ of the population, indicating the perivascular macrophage population was quite small (Fig. $4 d$ ).

\section{Hippocampal microglia/macrophages from NI rats express greater IL-1 $\beta$ ex vivo compared with controls}

Next, we determined whether microglia from NI rats express more IL- $1 \beta$ to an LPS challenge ex vivo compared with controls. First, the HP was removed from untreated adult rats and a singlecell suspension was obtained using myelin depletion as described above. Isolated HP cells were magnetically sorted into CD11 ${ }^{+}$ and $\mathrm{CD} 11 \mathrm{~b}^{-}$fractions. HP CD $11 \mathrm{~b}^{+}$and $\mathrm{CD} 11 \mathrm{~b}^{-}$fractions were then cultured with and without LPS $(10 \mathrm{ng} / \mathrm{ml})$ for $4 \mathrm{~h}$. Immediately following culture, cells were lysed and total RNA was isolated for qPCR of relative IL- $1 \beta$ gene expression. IL- $1 \beta$ was only detected in the $\mathrm{CD}_{11} \mathrm{~b}^{+}$fraction, and its expression was increased following LPS in our group of unmanipulated control rats (Fig. 5a). Next, we repeated this experiment using CD11 ${ }^{+}$ 
cells isolated from adult rats in each neonatal treatment group $(n=6$ per group). There was a significant effect of neonatal treatment $\left(F_{(1,8)}=8.2 ; p=\right.$ $0.02)$; IL- $1 \beta$ expression was significantly higher in NI rats, both in response to media and to LPS (Fig. $5 b$ ). This increase did not require an in vivo LPS challenge, suggesting that priming is intrinsic to microglia in NI rats and does not require an acute interaction with other cell types. While the basal increase in IL- $1 \beta$ in the NI plus media group may be a consequence of the isolation procedure itself, microglia are regardless more reactive in NI rats.

The exaggerated increase in IL-1 $\beta$ in vivo in NI rats is microglial derived and requires learning

Our first experiment demonstrated that CD11b expression reflects the pattern of IL-1 $\beta$ protein within the HP (Figs. 1,2 ). Moreover, microglia from NI rats express exaggerated IL-1 $\beta$ ex vivo (Fig. 5). However, exaggerated expression of both $\mathrm{CD} 11 \mathrm{~b}$ and IL- $1 \beta$ in vivo were only observed in conjunction with fear conditioning (Figs. 1, 2). To determine whether microglia are the source of exaggerated microglia during learning, we measured the expression of IL- $1 \beta$ from directly isolated $\mathrm{CD} 11 \mathrm{~b}^{+}$cells following either Fear Conditioning or Shock alone. Adult rats from each neonatal treatment group were injected intraperitoneally with either saline or LPS $24 \mathrm{~h}$ before Fear Conditioning ( $n=6-7$ /group) or Shock ( $n=4-5$ /group), and brains were collected $1 \mathrm{~h}$ later following cold saline perfusion. The HP was extracted and microglia were isolated using myelin depletion and $\mathrm{CD} 1 \mathrm{~b}^{+}$selection as described above. Cells were immediately lysed and total RNA was isolated for qPCR of relative IL-1 $\beta$ gene expression. Following fear conditioning, there were significant effects of group $\left(F_{(1,26)}=4.7 ; p=0.041\right)$ and injection $\left(F_{(1,26)}=6.1 ; p=0.021\right)$ (Fig. $\left.6 a\right)$, with expression highest in the NI plus LPS group. In contrast, there were no significant effects of neonatal treatment in the Shock only group (Fig. 6b). In a separate control experiment, $\mathrm{CD}_{11 \mathrm{~b}^{-}}{ }^{-}$cells were selected from the HP of rats in each neonatal treatment that received Fear Conditioning $1 \mathrm{~h}$ before killing as above ( $n=2$ /group), to confirm that microglia/macrophages are the primary source of IL- $1 \beta$ in response to fear conditioning. Figure $6 c$ illustrates that IL- $1 \beta$ mRNA was completely undetectable in the population of $\mathrm{CD} 1 \mathrm{~b}^{-}$cells, consistent with our previous in vitro findings (Fig. 5b). Finally, to further characterize the CD11b ${ }^{-}$ population, we assessed GFAP and CX3CL1 mRNA; both were highly expressed in $\mathrm{CD} 11 \mathrm{~b}^{-}$cells but not CD11b ${ }^{+}$cells (Fig. $6 d$ ), indicating the $\mathrm{CD}_{11 \mathrm{~b}^{-}}$population contained astrocytes and neurons, respectively, which were viable and responsive to LPS.
Fear Conditioning

CD200

CD200R

b

CD200 CD200R

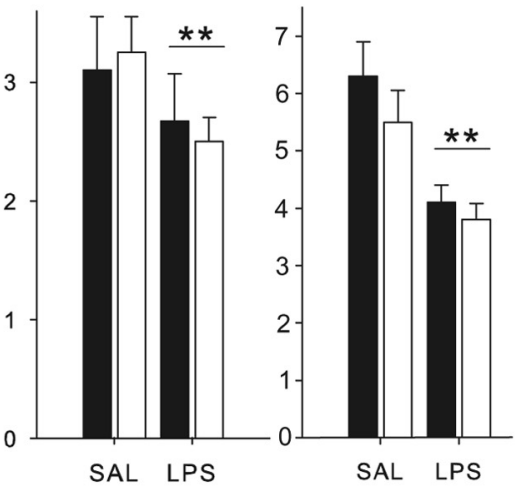

d

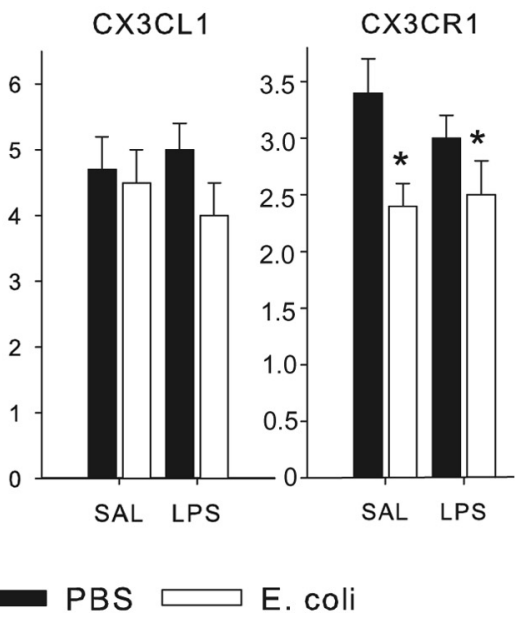

Neonatal Treatment:
CX3CR1

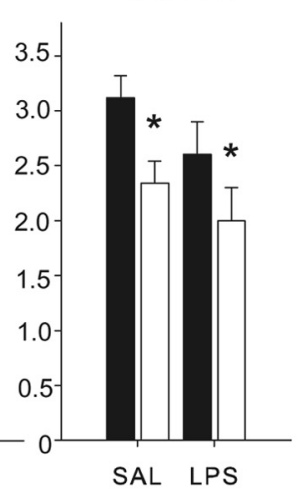

Shock only

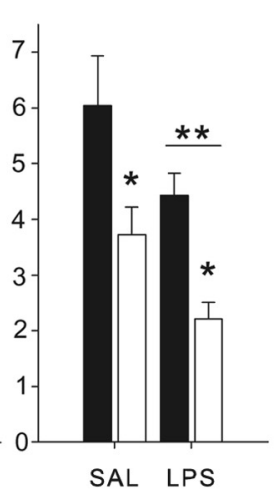

SAL LPS

SAL LPS

CX3CR 1

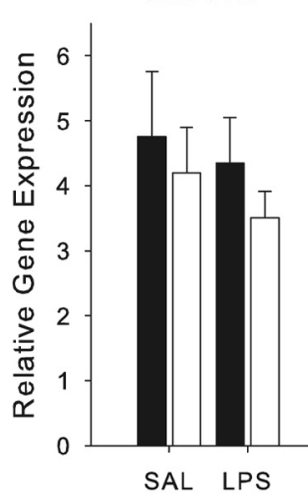

Figure 3. NI rats exhibit decreased neuronal inhibition within the HP compared with controls. Rats treated with PBS or E. colion P4 were injected as adults with SAL or LPS, and $24 \mathrm{~h}$ later received Fear Conditioning or Shock only ( $n=8 /$ group). Brains were collected $2 \mathrm{~h}$ later, and target genes were assessed. $\boldsymbol{a}, \mathrm{CD} 200$ and its receptor (CD200R) were reduced overall in NI rats compared with controls in the fear conditioned group $\left({ }^{*} p<0.01\right.$ for both), whereas only CD200R was significantly decreased by LPS $\left({ }^{* *} p<\right.$ decreased by LPS $\left({ }^{* *} p<0.02\right)$. c, $\boldsymbol{d}$, Fractalkine receptor (CX3CR1) but not its ligand was reduced overall in NI rats in both Fear Conditioned and Shock only groups. ( ${ }^{*} p<0.05$ for all, compared with PBS). Error bars indicate SEM.

Minocycline prevents the exaggerated hippocampal IL-1 $\beta$ response, and the memory impairment in adult rats infected as neonates

Our final goal was to prevent the memory impairment in NI rats by pharmacologically inhibiting microglia. To do this, we used the microglial inhibitor MINO, which we administered via oral gavage to mimic the clinical route of administration and to avoid the visceral irritation that occurs following intraperitoneal injection (our unpublished observations). In our first experiment, rats from each neonatal treatment group were injected with LPS as adults, and fear conditioned $24 \mathrm{~h}$ later (Fig. $7 a$ ). Rats also received a loading dose of MINO (50 mg/kg) or its vehicle (water) in a volume of $5 \mathrm{ml} / \mathrm{kg}$ via oral gavage $12 \mathrm{~h}$ before LPS injection, and received a second dose (water or $25 \mathrm{mg} / \mathrm{kg}$ ) $1 \mathrm{~h}$ before injection. This dosing regimen significantly decreases proinflammatory cytokine production by microglia (Hutchinson et al., 2008). Contextual memory was assessed $72 \mathrm{~h}$ after conditioning in one-half of the animals in each group ( $n=10$ /group MINO treated, and $n=8$ /group water treated). In the remaining animals $(n=8-10$ / 
a

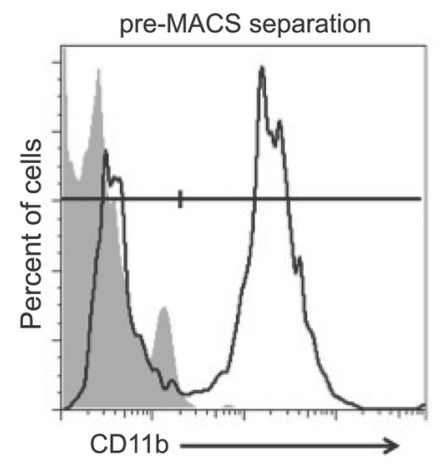

b

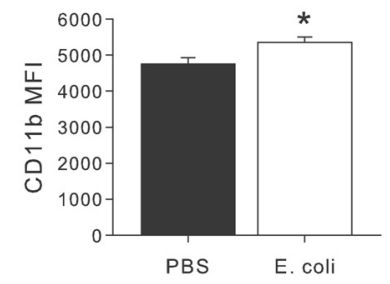

C

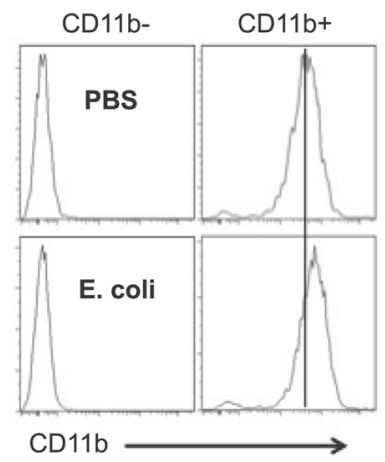

d

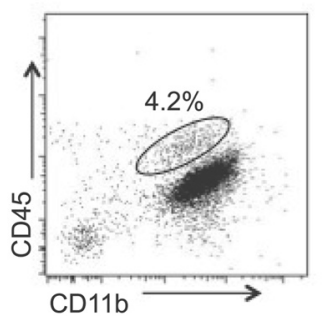

Figure 4. NI rats exhibit increased surface antigen expression of CD11b on isolated HP microglia. $\boldsymbol{a}$, Adult rat HP were microdissected following cold saline perfusion and brought to single-cell suspensions using Miltenyi's Neural Dissociation Kit followed by myelin depletion. Myelin-depleted cells were stained with APC-conjugated CD11b and analyzed using flow cytometry. Representative presorted populations are shown as distinct peaks. An unstained control is overlaid for reference (shaded histogram). $\boldsymbol{b}$, Myelin-depleted cells from rats in each neonatal treatment group were stained with APC-conjugated CD11b to assess expression on microglia independent of selection using magnetic beads, which could influence antigen expression. The bar graph shows greater average ( \pm SEM) MFI for CD11b reactivity from NI ( $n=$ 10) compared with PBS $(n=9)$ rats $\left({ }^{*} p<0.05\right)$. c, Myelin-depleted cells from rats in each neonatal treatment group were sorted into $\mathrm{CD} 11 \mathrm{~b}^{+}$and $\mathrm{CD} 11 \mathrm{~b}^{-}$fractions using magnetic beads. Representative postsorted (MACS) populations are shown. Purity was consistently $>93 \% \mathrm{CD}_{11 \mathrm{~b}}{ }^{+}$and $\sim 99 \% \mathrm{CD}_{11 \mathrm{~b}}{ }^{-}$for all samples. A rightward shift can be seen in the population of $\mathrm{CD}_{11 \mathrm{~b}^{+}}{ }^{+}$cells from NI rats, indicating increased expression (vertical line is provided for comparison). $\boldsymbol{d}$, Sorted CD11 ${ }^{+}$cells were stained with APC-conjugated CD11b/c and CD45 (a marker highly expressed on infiltrating macrophages), which revealed a large, dense cluster of CD11b ${ }^{\text {high }} /$ CD $45^{\text {low }}$ cells. In contrast, CD11b ${ }^{\text {high }}$ cells that also stained brightly for CD45 accounted for only $4.2 \%$ of the population, indicating the perivascular macrophage population was minimal.

group), brains were collected $2 \mathrm{~h}$ after fear conditioning to assess IL-1 $\beta$ protein within the HP. For freezing behavior, there was a significant group by drug interaction $\left(F_{(1,35)}=7.3 ; p=0.01\right)$. Freezing was lower in NI plus water rats compared with all other groups ( $p<0.03$ for all), and MINO given before LPS completely reversed this (Fig. $7 b$ ). For IL- $1 \beta$ protein, there was a significant interaction as well $\left(F_{(1,35)}=4.9 ; p=0.034\right)$; NI rats had higher IL- $1 \beta$ concentrations than controls when treated with water before LPS ( $p=0.01$ ), whereas MINO given before LPS prevented this increase (Fig. $7 d$, left panel).

In a second group of rats, we determined whether MINO given just before fear conditioning but after LPS would similarly restore memory in NI rats (Fig. 7). With this paradigm, a normal inflammatory response to LPS was allowed to occur before MINO administration, allowing us to confirm our hypothesis that exaggerated microglial-derived IL- $1 \beta$ production at the time of learning is critical for the observed memory impairment. Thus, rats from each neonatal treatment were injected with LPS as adults, and fear conditioned $24 \mathrm{~h}$ later as before. All rats also received MINO $12 \mathrm{~h}$ and again $1 \mathrm{~h}$ before fear conditioning (12 and $23 \mathrm{~h}$ after LPS injections). There were no significant differ-

a

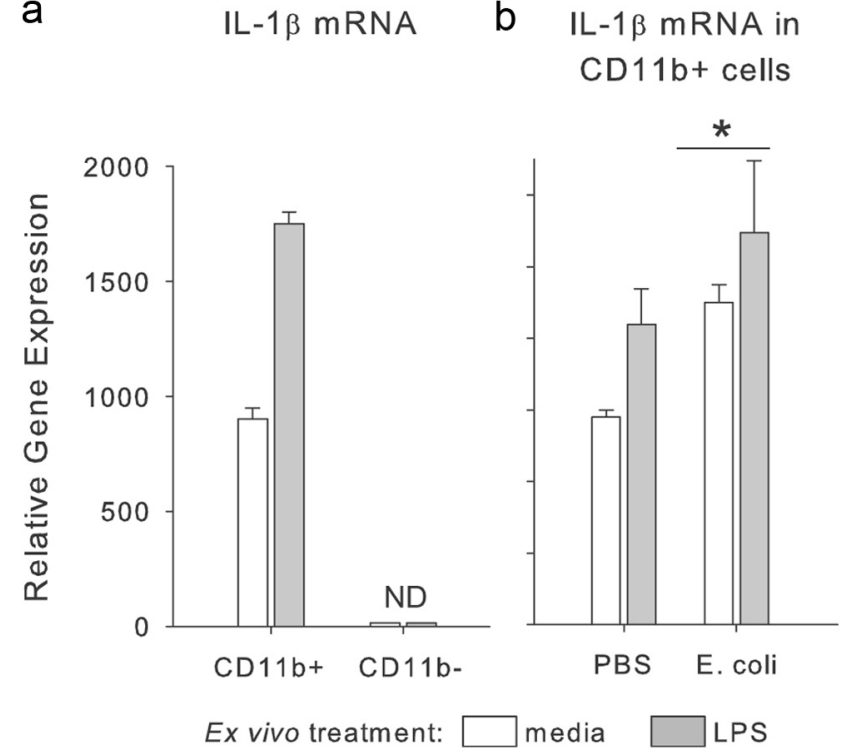

Figure 5. Isolated HP microglia from NI rats express exaggerated IL-1 $\beta$ mRNA ex vivo. $\boldsymbol{a}$, Microglia were rapidly isolated from the adult HP of rats using myelin depletion and CD11 $\mathrm{b}^{+}$ selection as described above in Figure 4. HP CD11 ${ }^{+}$and CD11 ${ }^{-}$fractions were cultured with and without LPS ( $10 \mathrm{ng} / \mathrm{ml})$ for $4 \mathrm{~h}$ at $37^{\circ} \mathrm{C}$. Immediately following culture, cells were lysed and total RNA isolated for RT-PCR. Relative IL- $1 \beta$ gene expression to GAPDH is shown, which is increased in response to LPS and undetectable in the CD11b ${ }^{-}$population ( $n=2 /$ group). $\boldsymbol{b}$, Microglia were isolated from the adult HP of rats from each neonatal treatment. CD11b ${ }^{+}$cells from $N I$ rats express greater relative expression of IL- $1 \beta$ with or without LPS stimulation ex vivo, compared with controls ( ${ }^{*} p=0.02$ ). The bars represent the average ( \pm SEM) relative expression values for two rat HPs (pooled) per treatment group per day run as three independent experiments ( $n=6 /$ group).

ences among groups in percentage freezing to the context (Fig. $7 c$ ), indicating that MINO before conditioning also prevented the memory impairment in NI rats, even in the face of prior LPS. For IL- $1 \beta$ protein, there was also no group difference (Fig. $7 d$, right panel), indicating that MINO before fear conditioning prevented the exaggerated increase we had previously observed in NI plus water rats (left panel).

Because MINO can have sedative properties, we included a group of saline-injected rats in the latter experiment to confirm that MINO itself does not impair learning; freezing levels were comparable with LPS-treated and water-gavaged rats in the previous experiment. Finally, we also assessed activity levels in a separate group of untreated adult rats $(n=5 /$ group, water vs MINO) using an open field. This test was performed $1 \mathrm{~h}$ after the second gavage, at the time that fear conditioning would normally occur. Consistent with the results for fear conditioning, MINO did not alter overall activity in the open field compared with water-treated controls (total activity counts, mean \pm SEM: water, $1000 \pm 230$; MINO, $1090 \pm 220 ; p>0.05$; data not shown).

\section{Discussion}

Bacterial infection early in life leads to marked HP-dependent long-term memory impairments in adulthood, but only when combined with a "second hit," an LPS challenge before learning, consistent with our previous findings (Bilbo et al., 2006). The primary goal of this study was to determine the cellular source of HP IL- $1 \beta$ in NI rats, which we have demonstrated is exaggerated in response to LPS and causally linked to the memory impairment (Bilbo et al., 2005b). We sought to determine the mechanism by which long-term changes in immune reactivity within the brain can endure in response to an initial insult, potentially 
a

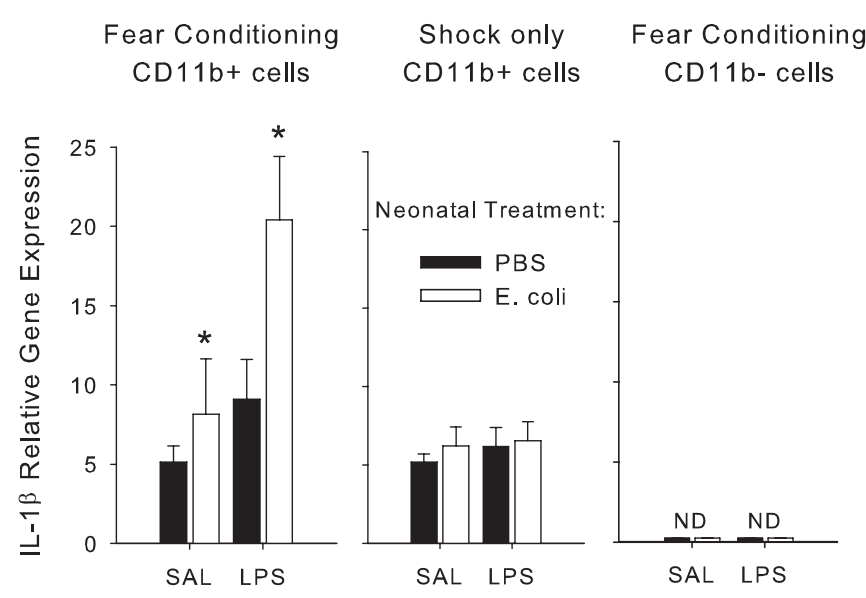

d

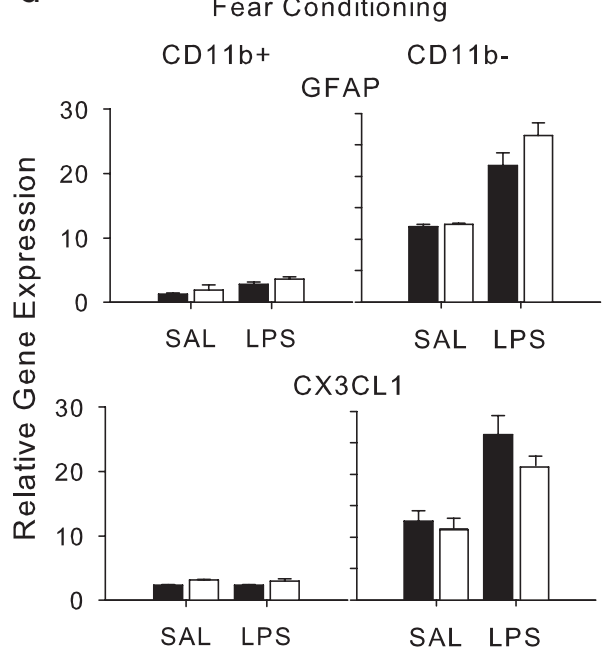

Figure 6. HP microglia isolated $1 \mathrm{~h}$ after behavioral experience express exaggerated IL-1 $\beta \mathrm{mRNA}$ in NI rats compared with controls, but only following learning. Rats treated with PBS or E. coli on P4 were injected as adults with SAL or LPS, and received Fear Conditioning or Shock only $24 \mathrm{~h}$ later. Microglia were rapidly isolated $1 \mathrm{~h}$ later using myelin depletion and CD11b ${ }^{+}$selection as described above in Figure 4. Isolated microglia were immediately lysed and total RNA isolated for RT-PCR. Relative IL-1 $\beta$ gene expression to GAPDH is shown. $\boldsymbol{a}$, IL- $1 \beta \mathrm{mRNA}$ expression was higher overall in NI rats ( $\left.{ }^{*} p=0.04\right)$ and higher in response to LPS in both groups ( $\left.{ }^{*} p=0.02\right)(n=6-7 /$ group). $\boldsymbol{b}$, There were no group differences $1 \mathrm{~h}$ following Shock alone $(p>0.05 ; n=4-5 / \mathrm{group})$. c, IL-1 $\beta$ mRNA was undetectable in CD11b ${ }^{-}$cells collected from a separate group of rats in each condition that also received fear conditioning ( $n=2 /$ group). $\boldsymbol{d}$, GFAP and fractalkine/CX3CL1 were robustly expressed in $\mathrm{CD}_{11 \mathrm{~b}}{ }^{-}$cells, indicating this population contained astrocytes and neurons, and was viable and responsive to LPS. Error bars indicate SEM.

throughout life, and thereby lend insight into the environmental risk factors for neurodegenerative and inflammatory disorders that exhibit a broad spectrum of prevalence and severity that cannot be explained by genetics alone.

We show for the first time that $\mathrm{CD}_{11 \mathrm{~b}}{ }^{+}$cells are the sole source of IL- $1 \beta$ in response to normal HP-dependent learning and that early-life events can significantly modulate learning-dependent cytokine activity within the HP via a specific, enduring effect on microglial function. As noted previously, our population of $\mathrm{CD} 11 \mathrm{~b}^{+}$cells does not exclude resident perivascular macrophages; however, this population is quite small $(\sim 4 \%)$. The resident microglia are functionally primed within the HP as a consequence of the early-life infection; specifically, microglia from NI rats express greater CD11b on a per-cell basis and produce more IL- $1 \beta$ ex vivo compared with microglia from controls. Furthermore, blocking microglial activation with MINO prevents both the sensitized IL-1 $\beta$ response and the cognitive impairment in NI rats. Importantly, the sensitized IL- $1 \beta$ response $24 \mathrm{~h}$ after LPS in NI rats in vivo requires a learning experience, as Footshock or Context exposure alone does not elicit the same exaggerated response. Moreover, IL- $1 \beta$ protein was completely undetectable within cortical regions of saline-injected rats that experienced fear conditioning, whereas concentrations were low but detectable in the HP of all rats. Thus, the learning experi- a

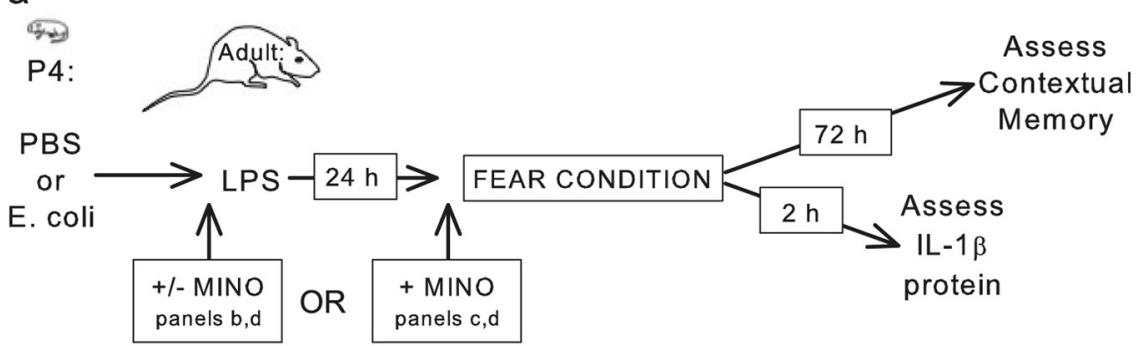

b
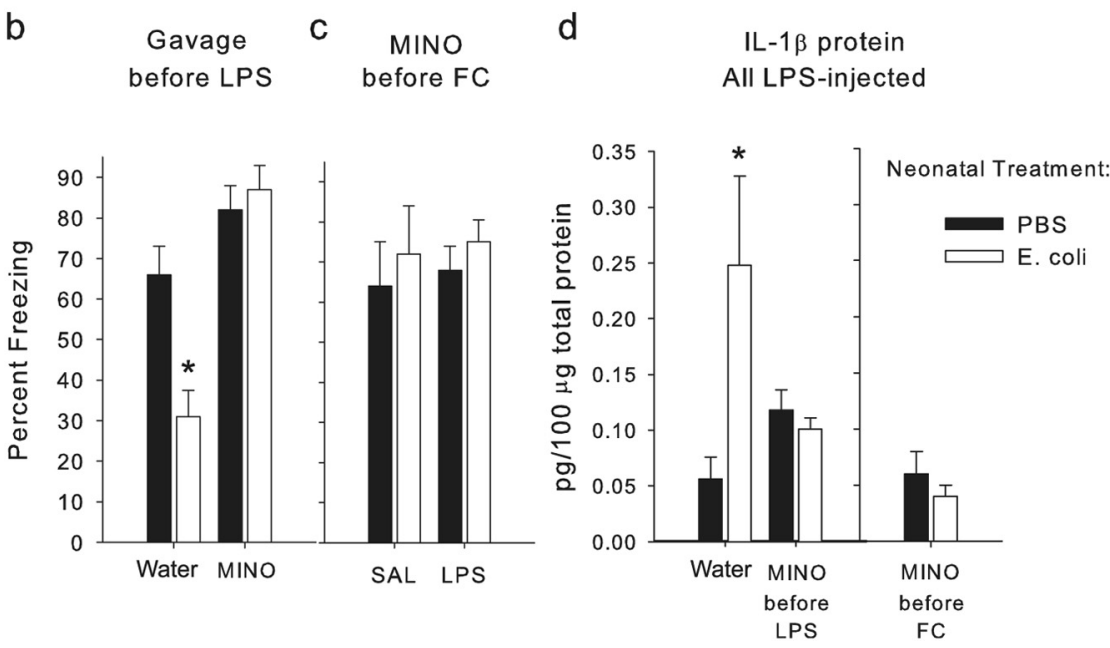

Figure 7. Inhibiting microglia before LPS or before learning prevents the memory impairment and exaggerated IL-1 $\beta$ response in NI rats. $\boldsymbol{a}$, Adult rats treated on P4 with PBS or E. coli were injected with LPS $24 \mathrm{~h}$ before fear conditioning. A subset of animals were killed $2 \mathrm{~h}$ later to assess HP IL-1 $\beta$ protein, and the remaining animals were tested for memory at $72 \mathrm{~h} . \boldsymbol{b}$, Rats in each neonatal treatment group ( $n=10$ group) received water or MIN0 $12 \mathrm{~h}$ and again $1 \mathrm{~h}$ before LPS in the experimental paradigm illustrated in $\boldsymbol{a}$. Freezing was significantly lowest in NI rats that received water before LPS $\left({ }^{*} p<0.03\right)$, but this decrease was prevented by MINO. c, A separate group of rats in each neonatal treatment group ( $n=10 /$ group) received MIN0 $12 \mathrm{~h}$ and again $1 \mathrm{~h}$ before Fear Conditioning (FC), but after LPS the previous day. A SAL-injected group was also included to ensure that MINO alone did not impair learning. There were no differences between groups. $\boldsymbol{d}, \mathrm{IL}-1 \beta$ protein was significantly highest in $\mathrm{NI}$ rats that received water before LPS ( ${ }^{*} p=0.03$ ) (left-most bars), but this increase was prevented by MIN0, administered either before LPS (center bars), or in a separate group, after LPS but before FC (right-most bars). Error bars indicate SEM. 
ence itself induced IL- $1 \beta$ expression in a HP-restricted manner. Finally, preventing microglial activation during learning prevented the memory deficit in NI rats, even following an adult LPS challenge.

There is a significant literature documenting the role of IL-1 $\beta$ in both normal memory and in memory disruption (Yirmiya and Goshen, 2011). Physiological levels of IL-1 $\beta$ are required for memory, whereas aberrant levels (either too low or too high) become detrimental and are strongly associated with disorders like AD. IL-1 $\beta$ mRNA increases as a consequence of learning (Goshen et al., 2007; Labrousse et al., 2009). Furthermore, IL-1 type 1 receptor expression in astrocytes is important for HPdependent LTP and long-term memory (Ben Menachem-Zidon et al., 2011). However, the source of IL- $1 \beta$ during learning has not been demonstrated, and neurons, astrocytes, and microglia, among other cells, are thought to produce IL- $1 \beta$ within the brain (Rothwell, 1991). We show that learning, but not Shock or Context exposure alone, induces IL- $1 \beta$ protein specifically within the $\mathrm{HP}$, and that its expression is markedly exaggerated in NI rats given LPS $24 \mathrm{~h}$ before. Moreover, we replicated this pattern for mRNA in purified CD11b ${ }^{+}$cells (Fig. 6), whereas IL-1 $\beta$ mRNA was completely undetectable in the population of CD11b ${ }^{-}$cells, regardless of behavioral experience (Figs. 5, 6). Together, we have demonstrated that microglia are primed as a consequence of neonatal infection and that this priming leads to aberrant production of IL- $1 \beta$ specifically during learning in adulthood. Importantly, these data suggest that the resident microglia of the HP are a necessary component of normal memory formation.

The vulnerability factors leading to cytokine dysregulation within a given individual are not well understood, as the majority of research on IL- $1 \beta$ and cognition has been conducted in genetic mouse models either entirely lacking IL-1 or its receptor, or with overexpression of its antagonist, IL-1ra (Yirmiya and Goshen, 2011). Similarly, glial function has often been explored in models of induced injury (e.g., stroke, trauma) in which the precipitating event is intrinsic to the model, creating questions about etiology that are difficult to answer. There is compelling evidence from the neurodegeneration and aging literatures that microglia become sensitized or primed following initial activation (by largely unknown factors), which contribute to neuronal dysfunction or death (Cunningham et al., 2005; Perry et al., 2007; Godbout and Johnson, 2009; Henry et al., 2009). Notably, primed glia do not constitutively overproduce proinflammatory mediators. However, the response by primed glia to a subsequent challenge (e.g., systemic infection) is significantly exaggerated, compared with resting/quiescent glia that receive the same challenge (Perry et al., 2007). This pattern of sensitization is similar to the phenotype we observe in our "two-hit" model. However, our data provide the first evidence to our knowledge that early-life experience can change microglial function within the brain well beyond the initial insult, perhaps for the remainder of the life span. Indeed, we have demonstrated that NI rats exhibit accelerated cognitive decline in middle age (16 months), independent of acute immune challenge, a change that is linked to exaggerated aging-related glial sensitization (Bilbo, 2010). Thus, aging itself, and its impact on glial reactivity, acts as a "second hit" only in rats made vulnerable by neonatal infection.

Increasing evidence suggests a role for microglia in normal synaptic plasticity mechanisms within the adult brain, including dendritic spine remodeling and elimination (Tremblay and Majewska, 2011). These cells are active and dynamic even when "quiescent" (Nimmerjahn et al., 2005) (e.g., they continually survey their microenvironments by extending and contracting processes into nearby synapses with a frequency that is activity dependent) (Wake et al., 2009; Tremblay et al., 2010). They have receptors for multiple neurotransmitters, including those important for learning and memory (e.g., ATP, norepinephrine, glutamate) (Pocock and Kettenmann, 2007). The requirement of learning to observe the exaggerated IL- $1 \beta$ response in NI rats 24 $\mathrm{h}$ after LPS in vivo implies a neuronal-glial interaction. CD200 and CX3CL1 are both expressed by neurons within the brain and tonically inhibit microglia via CD200R and CX3CR1, respectively (Harrison et al., 1998; Barclay et al., 2002). Notably, these inhibitory factors decrease during aging and in neurodegenerative disorders like $\mathrm{AD}$, likely contributing to increased microglial reactivity (Frank et al., 2006; Corona et al., 2010; Lue et al., 2010). Mice deficient in fractalkine receptor, CX3CR1, exhibit enhanced Tau pathology within the HP that is dependent upon microglialderived IL-1 $\beta$ (Bhaskar et al., 2010). In our study, CX3CL1 did not differ by group, whereas its receptor was decreased basally in NI rats, implicating a change at the level of microglia. In contrast, CD200 and its receptor were both reduced basally in NI rats, but only following fear conditioning. These data suggest there may be a rapid chemokine role for CD200 in synaptic plasticity similar to that already described for CX3CL1, which plays a role in AMPA receptor function in active synapses (Ragozzino et al., 2006), but this hypothesis remains to be explored.

The mechanism by which learning leads to microglial production of IL- $1 \beta$ within the HP also remains to be determined. One notable finding in this study was that MINO before FC did not impair memory, given that constitutive levels of IL- $1 \beta$ are considered vital for memory formation as discussed previously. However, MINO did not completely suppress IL-1 $\beta$ in either group of rats (Fig. $7 d$ ). Thus, while the protein concentrations are low, they are detectable, in contrast to saline-injected rats that do not receive fear conditioning (Fig. 1d). Therefore MINO-treated rats likely maintain a threshold amount of IL- $1 \beta$ protein needed for memory consolidation. If true, this suggests that MINO prevents the production of IL- $1 \beta$ in response to an inflammatory stimulus (LPS), but not in response to a learning-induced stimulus/signal, which may be neurotransmitter/hormone mediated. Finally, there is evidence that MINO increases rather than suppresses the release of IL-1 $\alpha$ (Célérier et al., 1996; Yamaki et al., 1998), which has also been implicated in LTP (Ross et al., 2003). Importantly, these potential mechanisms of memory formation in the face of MINO are not mutually exclusive and remain to be further explored.

In closing, we demonstrate for the first time that $\mathrm{CD} 11 \mathrm{~b}{ }^{+}$cells are the primary source of IL- $1 \beta$ within the HP during normal learning. Minocycline is an imperfect microglial inhibitor with nonspecific antiinflammatory properties. However, our pharmacological and behavioral experiments combined with the finding that IL- $1 \beta$ was produced exclusively in $\mathrm{CD} 11 \mathrm{~b}^{+}$cells directly as a consequence of learning strongly point to a critical role of microglia in normal learning. Most importantly, we have identified an early-life risk factor that alters the normal, activity-dependent "set point" of IL- $1 \beta$ via a specific, enduring impact on microglia. Microglia derive from primitive yolk sac macrophage precursors, which are of mesodermal origin and enter the neuroectoderm during embryogenesis, a founding colony of which proliferates to populate the entire developing parenchyma (Ginhoux et al., 2010). Importantly, adult microglia in normal rodents are thought to arise exclusively from the founding population of primitive macrophages, with little or no contribution from peripheral bone marrow-derived myeloid precursors after initial colonization and proliferation during development (Ginhoux et al., 2010). Thus, early-life events may exert enduring impacts on 
the brain and behavior of organisms via an impact on the function of these resident, long-lived immune cells. The hypothesis that the early-life environment is especially critical in determining later risk for disorders like $\mathrm{AD}$ is supported clinically (Moceri et al., 2000; Gatz et al., 2006). Furthermore, in young adult humans, there is significant variability in learning and memory impairments following low-dose endotoxin treatment that is inversely correlated to induced circulating cytokine levels (Krabbe et al., 2005). Our data provide valuable insight into the mechanisms underlying such variability and suggest the interesting possibility that changes in cognition following low-dose endotoxin challenge in young adults may serve as a novel biomarker for increased risk of later-life dementia. This possibility, as well as the role of microglia and their secreted molecules in normal synaptic plasticity mechanisms more generally, warrants further research.

\section{References}

Barclay AN, Wright GJ, Brooke G, Brown MH (2002) CD200 and membrane protein interactions in the control of myeloid cells. Trends Immunol 23:285-290.

Barrientos RM, Higgins EA, Sprunger DB, Watkins LR, Rudy JW, Maier SF (2002) Memory for context is impaired by a post context exposure injection of interleukin-1 beta into dorsal hippocampus. Behav Brain Res 134:291-298.

Barrientos RM, Frank MG, Hein AM, Higgins EA, Watkins LR, Rudy JW, Maier SF (2009) Time course of hippocampal IL-1 beta and memory consolidation impairments in aging rats following peripheral infection. Brain Behav Immun 23:46-54.

Ben Menachem-Zidon O, Avital A, Ben-Menahem Y, Goshen I, Kreisel T, Shmueli EM, Segal M, Ben Hur T, Yirmiya R (2011) Astrocytes support hippocampal-dependent memory and long-term potentiation via interleukin-1 signaling. Brain Behav Immun 25:1008-1016.

Bennet L, Gunn A (2006) The fetal origins of adult mental illness. In: Early life origins of health and disease. Advances in experimental medicine and biology (Wintour-Coghlan M, Owens J, eds), pp 204-211. New York: Springer.

Bhaskar K, Konerth M, Kokiko-Cochran ON, Cardona A, Ransohoff RM, Lamb BT (2010) Regulation of tau pathology by the microglial fractalkine receptor. Neuron 68:19-31.

Bilbo SD (2010) Early-life infection is a vulnerability factor for aging-related glial alterations and cognitive decline. Neurobiol Learn Mem 94:57-64.

Bilbo SD, Schwarz JM (2009) Early-life programming of later-life brain and behavior: a critical role for the immune system. Front Behav Neurosci 3:14.

Bilbo SD, Levkoff LH, Mahoney JH, Watkins LR, Rudy JW, Maier SF (2005a) Neonatal infection induces memory impairments following an immune challenge in adulthood. Behav Neurosci 119:293-301.

Bilbo SD, Biedenkapp JC, Der-Avakian A, Watkins LR, Rudy JW, Maier SF (2005b) Neonatal infection-induced memory impairment after lipopolysaccharide in adulthood is prevented via caspase- 1 inhibition. J Neurosci 25:8000-8009.

Bilbo SD, Rudy JW, Watkins LR, Maier SF (2006) A behavioural characterization of neonatal infection-facilitated memory impairment in adult rats. Behav Brain Res 169:39-47.

Bilbo SD, Newsum NJ, Sprunger DB, Watkins LR, Rudy JW, Maier SF (2007) Differential effects of neonatal handling on early life infection-induced alterations in cognition in adulthood. Brain Behav Immun 21:332-342.

Bilbo SD, Yirmiya R, Amat J, Paul ED, Watkins LR, Maier SF (2008a) Bacterial infection early in life protects against stressor-induced depressivelike symptoms in adult rats. Psychoneuroendocrinology 33:261-269.

Bilbo SD, Barrientos RM, Eads AS, Northcutt A, Watkins LR, Rudy JW, Maier SF (2008b) Early-life infection leads to altered BDNF and IL-1beta mRNA expression in rat hippocampus following learning in adulthood. Brain Behav Immun 22:451-455.

Bilbo SD, Wieseler JL, Barrientos RM, Tsang V, Watkins LR, Maier SF (2010) Neonatal bacterial infection alters fever to live and simulated infections in adulthood. Psychoneuroendocrinology 35:369-381.

Bland ST, Beckley JT, Watkins LR, Maier SF, Bilbo SD (2010) Neonatal Escherichia coli infection alters glial, cytokine, and neuronal gene expres- sion in response to acute amphetamine in adolescent rats. Neurosci Lett 474:52-57.

Célérier P, Litoux P, Dréno B (1996) In vitro modulation of epidermal inflammatory cytokines (IL-1 alpha, IL-6, TNF alpha) by minocycline. Arch Dermatol Res 288:411-414.

Chomczynski P, Sacchi N (1987) Single-step method of RNA isolation by acid guanidinium thiocyanate-phenol-chloroform extraction. Anal Biochem 162:156-159.

Corona AW, Huang Y, O'Connor JC, Dantzer R, Kelley KW, Popovich PG, Godbout JP (2010) Fractalkine receptor (CX3CR1) deficiency sensitizes mice to the behavioral changes induced by lipopolysaccharide. J Neuroinflammation 7:93.

Cunningham C, Wilcockson DC, Campion S, Lunnon K, Perry VH (2005) Central and systemic endotoxin challenges exacerbate the local inflammatory response and increase neuronal death during chronic neurodegeneration. J Neurosci 25:9275-9284.

Ford AL, Goodsall AL, Hickey WF, Sedgwick JD (1995) Normal adult ramified microglia separated from other central nervous system macrophages by flow cytometric sorting. Phenotypic differences defined and direct ex vivo antigen presentation to myelin basic protein-reactive $\mathrm{CD} 4{ }^{+} \mathrm{T}$ cells compared. J Immunol 154:4309-4321.

Frank MG, Barrientos RM, Biedenkapp JC, Rudy JW, Watkins LR, Maier SF (2006) mRNA up-regulation of MHC II and pivotal pro-inflammatory genes in normal brain aging. Neurobiol Aging 27:717-722.

Gallo P, Frei K, Rordorf C, Lazdins J, Tavolato B, Fontana A (1989) Human immunodeficiency virus type 1 (HIV-1) infection of the central nervous system: an evaluation of cytokines in cerebrospinal fluid. J Neuroimmunol 23:109-116.

Gatz M, Prescott CA, Pedersen NL (2006) Lifestyle risk and delaying factors. Alzheimer Dis Assoc Disord 20:S84-S88.

Ginhoux F, Greter M, Leboeuf M, Nandi S, See P, Gokhan S, Mehler MF, Conway SJ, Ng LG, Stanley ER, Samokhvalov IM, Merad M (2010) Fate mapping analysis reveals that adult microglia derive from primitive macrophages. Science 330:841-845.

Godbout JP, Johnson RW (2009) Age and neuroinflammation: a lifetime of psychoneuroimmune consequences. Immunol Allergy Clin North Am 29:321-337.

Goshen I, Kreisel T, Ounallah-Saad H, Renbaum P, Zalzstein Y, Ben-Hur T, Levy-Lahad E, Yirmiya R (2007) A dual role for interleukin-1 in hippocampal-dependent memory processes. Psychoneuroendocrinology 32:1106-1115.

Griffin WS, Stanley LC, Ling C, White L, MacLeod V, Perrot LJ, White CL 3rd, Araoz C (1989) Brain interleukin 1 and S-100 immunoreactivity are elevated in Down syndrome and Alzheimer disease. Proc Natl Acad Sci U S A 86:7611-7615.

Harrison JK, Jiang Y, Chen S, Xia Y, Maciejewski D, McNamara RK, Streit WJ, Salafranca MN, Adhikari S, Thompson DA, Botti P, Bacon KB, Feng L (1998) Role for neuronally derived fractalkine in mediating interactions between neurons and CX3CR1-expressing microglia. Proc Natl Acad Sci U S A 95:10896-10901.

Henry CJ, Huang Y, Wynne AM, Godbout JP (2009) Peripheral lipopolysaccharide (LPS) challenge promotes microglial hyperactivity in aged mice that is associated with exaggerated induction of both proinflammatory IL-1beta and anti-inflammatory IL-10 cytokines. Brain Behav Immun 23:309-317.

Hutchinson MR, Northcutt AL, Chao LW, Kearney JJ, Zhang Y, Berkelhammer DL, Loram LC, Rozeske RR, Bland ST, Maier SF, Gleeson TT, Watkins LR (2008) Minocycline suppresses morphine-induced respiratory depression, suppresses morphine-induced reward, and enhances systemic morphine-induced analgesia. Brain Behav Immun 22:1248-1256.

Krabbe KS, Reichenberg A, Yirmiya R, Smed A, Pedersen BK, Bruunsgaard H (2005) Low-dose endotoxemia and human neuropsychological functions. Brain Behav Immun 19:453-460.

Labrousse VF, Costes L, Aubert A, Darnaudéry M, Ferreira G, Amédée T, Layé $S$ (2009) Impaired interleukin-1beta and c-Fos expression in the hippocampus is associated with a spatial memory deficit in $\mathrm{P} 2 \mathrm{X}_{7}$ receptordeficient mice. PLoS One 4:e6006.

Livak KJ, Schmittgen TD (2001) Analysis of relative gene expression data using real-time quantitative PCR and the $2^{-\Delta \Delta C(T)}$ method. Methods 25:402-408.

Lue LF, Kuo YM, Beach T, Walker DG (2010) Microglia activation and 
anti-inflammatory regulation in Alzheimer's disease. Mol Neurobiol 41:115-128.

Meyers CA (2000) Neurocognitive dysfunction in cancer patients. Oncology (Williston Park) 14:75-79; discussion 79, 81-82, 85.

Moceri VM, Kukull WA, Emanuel I, van Belle G, Larson EB (2000) Earlylife risk factors and the development of Alzheimer's disease. Neurology 54:415-420.

Nimmerjahn A, Kirchhoff F, Helmchen F (2005) Resting microglial cells are highly dynamic surveillants of brain parenchyma in vivo. Science 308:1314-1318.

Perry VH, Cunningham C, Holmes C (2007) Systemic infections and inflammation affect chronic neurodegeneration. Nat Rev Immunol 7:161-167.

Pfaffl MW (2001) A new mathematical model for relative quantification in real-time RT-PCR. Nucleic Acids Res 29:e45.

Pocock JM, Kettenmann H (2007) Neurotransmitter receptors on microglia. Trends Neurosci 30:527-535.

Ragozzino D, Di Angelantonio S, Trettel F, Bertollini C, Maggi L, Gross C, Charo IF, Limatola C, Eusebi F (2006) Chemokine fractalkine/CX3CL1 negatively modulates active glutamatergic synapses in rat hippocampal neurons. J Neurosci 26:10488-10498.

Ross FM, Allan SM, Rothwell NJ, Verkhratsky A (2003) A dual role for interleukin-1 in LTP in mouse hippocampal slices. J Neuroimmunol 144:61-67.

Rothwell NJ (1991) Functions and mechanisms of interleukin 1 in the brain. Trends Pharmacol Sci 12:430-436.

Schneider H, Pitossi F, Balschun D, Wagner A, del Rey A, Besedovsky HO (1998) A neuromodulatory role of interleukin-1beta in the hippocampus. Proc Natl Acad Sci U S A 95:7778-7783.
Schwarz JM, Bilbo SD (2011) LPS elicits a much larger and broader inflammatory response than Escherichia coli infection within the hippocampus of neonatal rats. Neurosci Lett 497:110-115.

Spulber S, Mateos L, Oprica M, Cedazo-Minguez A, Bartfai T, Winblad B, Schultzberg M (2009) Impaired long term memory consolidation in transgenic mice overexpressing the human soluble form of IL-1ra in the brain. J Neuroimmunol 208:46-53.

Stanley LC, Mrak RE, Woody RC, Perrot LJ, Zhang S, Marshak DR, Nelson SJ, Griffin WS (1994) Glial cytokines as neuropathogenic factors in HIV infection: pathogenic similarities to Alzheimer's disease. J Neuropathol Exp Neurol 53:231-238.

Streit WJ (2005) Microglia and neuroprotection: implications for Alzheimer's disease. Brain Res Brain Res Rev 48:234-239.

Streit WJ (2010) Microglial activation and neuroinflammation in Alzheimer's disease: a critical examination of recent history. Front Aging Neurosci 2:22.

Tremblay MÈ, Majewska AK (2011) A role for microglia in synaptic plasticity? Commun Integr Biol 4:220-222.

Tremblay MÈ, Lowery RL, Majewska AK (2010) Microglial interactions with synapses are modulated by visual experience. PLoS Biol 8:e1000527.

Wake H, Moorhouse AJ, Jinno S, Kohsaka S, Nabekura J (2009) Resting microglia directly monitor the functional state of synapses in vivo and determine the fate of ischemic terminals. J Neurosci 29:3974-3980.

Yamaki K, Yoshida N, Kimura T, Ohbayashi H, Takagi K (1998) Effects of cytokines and minocycline on subacute lung injuries induced by repeated injection of lipopolysaccharide. Kansenshogaku Zasshi 72:75-82.

Yirmiya R, Goshen I (2011) Immune modulation of learning, memory, neural plasticity and neurogenesis. Brain Behav Immun 25:181-213. 